\title{
Hyperin and Quercetin Modulate Oxidative Stress-Induced Melanogenesis
}

\author{
You Jung Kim \\ Department of Dental Hygiene, Busan Women's College; Busanjin-gu, Busan 617-734, Korea. \\ Received July 5, 2012; accepted August 28, 2012; advance publication released online September 3, 2012
}

Hyperin and quercetin are phenolic compounds present in fruits and vegetables that have been reported to possess strong anti-oxidative properties. Although increasing evidence strongly suggests that antioxidants suppress the melanin synthesis that is causally associated with oxidative stress, the protective actions of hyperin and quercetin against oxidative stress-induced melanogenesis have not been fully explored. To elucidate the suppressive effects of hyperin and quercetin on oxidative stress and melanin synthesis, peroxynitrite $\left(\mathrm{ONOO}^{-}\right)$scavenging activity was measured in vitro as were quantifications of melanin content, intracellular total $\mathrm{RS}$, $\mathrm{ONOO}^{-}$, superoxide $\left(\mathrm{C}_{2}\right)$, nitric oxide $\left(\mathrm{NO}^{\circ}\right)$, catalase activity and the reduced glutathione (GSH)/ oxidized glutathione (GSSG) ratio. Results showed that in vitro, hyperin and quercetin reduced $\mathrm{ONOO}^{-}$. Additionally, hyperin and quercetin suppressed total $\mathrm{RS}, \mathrm{ONOO}^{-}, \mathrm{O}_{2}$, and $\mathrm{NO}^{\circ}$, catalase activity, and melanin synthesis, while they boosted the GSH/GSSG ratio in B16F10 melanoma cells (B16 cells). Therefore, I propose that hyperin and quercetin have a powerful capacity to modulate oxidative stress-induced melanogenesis.

Key words hyperin; quercetin; antioxidant; oxidative stress; melanogenesis

Melanogenesis is the process by which pigment forms and melanin is synthesized in special organelles called melanosomes. ${ }^{1)}$ Melanin plays a key role in the protection of the skin against deleterious sunlight under normal conditions, but also can increase the generation and excessive accumulation of melanin that lead to clinical and cosmetic concerns such as freckles, age spots, sites of actinic damage, and melasma. Chronic inflammation, UV ray radiation, and the release of abnormal $\alpha$-melanocyte stimulating hormone $(\alpha-\mathrm{MSH})$ also are well-known triggering factors for abnormal melanogenesis and inflammatory pigmentation., ${ }^{1,2}$

Oxidative stress caused by excessive reactive species (RS), including reactive oxygen species (ROS) and reactive nitrogen species (RNS), is known to be associated with skin aging and hyperpigmentation. Also, a deficient anti-oxidative defense system, such as a disturbed redox balance and weak anti-oxidant enzyme activity, exacerbate skin aging and hyperpigmentaion. ${ }^{3-5)}$ Therefore, searching for natural antioxidants that inhibit melanogenesis has been an important strategy in the development of skin medications and cosmetics. ${ }^{6}$ We have reported on the significance of maintaining cellular redox through the down-regulation of RS and the boosting of antioxidant defenses in the inhibition of melanogenesis. $5,7,78$

Various phenolic compounds from natural sources have been reported as melanogenic inhibitors. ${ }^{5,7-11)}$ Hyperin and quercetin are two phenolic flavonoids reported to have antioxidative $^{12)}$ and anti-viral ${ }^{13)}$ properties. However, the effects of hyperin and quercetin on oxidative stress-induced melanogenesis have not been fully explored to date.

To estimate the effects of hyperin and quercetin on oxidative insult in vitro, peroxynitrite $\left(\mathrm{ONOO}^{-}\right)$scavenging activity was measured. In addition, we used B16F10 melanoma cells (B16 cells) to investigate the effect of hyperin and quercetin on melanin content and performed measurements of several key oxidative and anti-oxidative markers: total RS generation, $\mathrm{ONOO}^{-}$, superoxide $\left(\mathrm{O}_{2}\right)$, nitric oxide $\left(\mathrm{NO}^{\circ}\right)$, reduced glutathione (GSH)/oxidized glutathione (GSSG) ratio, and

The author declares no conflict of interest. antioxidant enzyme (catalase) activity.

\section{MATERIALS AND METHODS}

Reagents L-Tyrosine, $\alpha-\mathrm{MSH}$, and other chemical reagents were purchased from Sigma Chemical Co. (St. Louis, MO, U.S.A.)

Cell Lines and Cultures B16 cells (from Korean Cell Line Bank, Korea) were maintained in Dulbecco's modified Eagle's medium (DMEM) medium supplemented with $10 \%$ fetal bovine serum (FBS, Gibco, NY, U.S.A.) containing penicillin/streptomycin $(100 \mathrm{IU} / 50 \mathrm{~g} / \mathrm{mL})$, at $37^{\circ} \mathrm{C}$ in a humidified atmosphere of $5 \% \mathrm{CO}_{2}$ and $95 \%$ air. These $\mathrm{B} 16$ cells were cultured in 24-well plates for each assay. All the experiments were performed in triplicate and repeated three times to ensure reproducibility.

Determination of Cell Viability The cell viability assay was carried out as described ${ }^{14)}$ using 3-(4,5-dimethylthiazol-2-yl)-2,5-diphenyltetrazolium bromide (MTT; Sigma Chemical Co.). Shortly thereafter, $5 \times 10^{4}$ cells/well were plated in a 24-well plate. After cells were exposed separately to hyperin and quercetin at concentrations of $5-100 \mu \mathrm{M}$ for $24 \mathrm{~h}$, MTT solutions were added and the insoluble derivative formed by cellular dehydrogenase was solubilized with EtOH-dimethyl sulfoxide (DMSO) $(1: 1$ mixture solution); the absorbance of each well was estimated at $560 \mathrm{~nm}$ using a microplate reader.

$\mathrm{ONOO}^{-}$Levels in Vitro $\mathrm{ONOO}^{-}$scavenging was measured by monitoring the oxidation of DHR 123 by the method of Kooy et al. ${ }^{15)}$ We added samples to the rhodamine buffer (pH 7.4) containing $6.25 \mu \mathrm{m}$ DHR 123 and $125 \mu \mathrm{M}$ DTPA and incubated the mixture for $5 \mathrm{~min}$ at $37^{\circ} \mathrm{C}$. Absorbance was measured at $500 \mathrm{~nm}$, which is the absorbance of rhodamine 123.

The Effect of Hyperin and Quercetin on Total RS Generation in B16 Cells Total RS production was measured in culture supernatant. ${ }^{16)}$ Twenty-five millimolar $2^{\prime}, 7^{\prime}$-dichlorofluorescein diacetate (DCFH-DA) was added to the incubation media, and changes in fluorescence were determined at an 
excitation wavelength of $486 \mathrm{~nm}$ and emission wavelength of $530 \mathrm{~nm}$ for $30 \mathrm{~min}$.

Measurement of $\mathrm{NO}^{*}$ Generation in B16 Cells $\mathrm{NO}^{\circ}$ generation was examined by measuring the accumulation of nitrite in the conditioned medium by the Griess assay. Briefly, $100 \mu \mathrm{L}$ of culture supernatant was allowed to react with $100 \mu \mathrm{L}$ of the Griess reagent ${ }^{17}$ ) and then incubated at room temperature for $5 \mathrm{~min}$. The optical density of the samples at $540 \mathrm{~nm}$ was read using a microplate reader.

Evaluation of ${ }^{\circ} \mathrm{O}_{2}$ Levels in B16 Cells ${ }^{\circ} \mathrm{O}_{2}$ levels were estimated following the method as previously described. ${ }^{18)}{ }^{\circ} \mathrm{O}_{2}-$ scavenging activity was evaluated by assessing the decrease in the ratio of the reduction of nitro blue tetrazolium (NBT). The culture supernatant was added to the reaction buffer (50 mM phosphate buffered saline (PBS) with $125 \mu \mathrm{M}$ ethylenediaminetetraacetic acid (EDTA), $62 \mu \mathrm{M}$ NBT and $98 \mu \mathrm{M}$ reduced nicotinamide adenine dinucleotide) containing $33 \mu \mathrm{M}$ 5 -methylphenazium methyl sulfate. The absorbance at $540 \mathrm{~nm}$, as an index of NBT reduction, was estimated after $5 \mathrm{~min}$.

Determination of $\mathrm{ONOO}^{-}$in $\mathbf{B 1 6}$ Cells $\mathrm{ONOO}^{-}$-dependent oxidation of dihydrorhodamine 123 (DHR 123) to rhodamine 123 was evaluated based on the method as described previously. ${ }^{15)}$ Samples were added to the rhodamine buffer (pH 7.4) containing 6.25 $\mu \mathrm{M}$ DHR 123 and $125 \mu \mathrm{M}$ diethylenetriaminepentaacetic acid (DTPA) and incubated $5 \mathrm{~min}$ at $37^{\circ} \mathrm{C}$. Absorbance was measured at $500 \mathrm{~nm}$, which is the absorbance of rhodamine 123.

Measurement of Catalase Activity in B16 Cells Catalase activity was estimated spectrophotometrically by direct measurement in the reduction of light absorption at $240 \mathrm{~nm}$ caused by the decomposition of hydrogen peroxide by catalase. ${ }^{19)}$

Estimation of GSH and GSSG Levels in B16 Cells GSH levels were assayed according to the method of Pandey and Katiyar. ${ }^{20)}$ Twenty-five percent of the meta-phosphoric acid-added cell pellets were centrifuged at $12000 \times \boldsymbol{g}$ for $10 \mathrm{~min}$, and then the supernatant was taken for assay. One millimolar EDTA-50 mm phosphate buffer was added to the supernatant followed by $o$-phthalaldehyde. After $20 \mathrm{~min}$ at room temperature, the fluorescence was measured at excitation wavelength of $360 \mathrm{~nm}$ and emission wavelength of $460 \mathrm{~nm}$. GSSG levels were determined after preincubation with $\mathrm{N}$ ethylmaleimide for $20 \mathrm{~min}$, and $0.1 \mathrm{M} \mathrm{NaOH}$ was replaced for $1 \mathrm{~mm}$ EDTA-50 mm phosphate buffer.

Determination of Melanogenesis in B16 Cells In this present study, the amount of melanin content was used as an index of melanogenesis. An assay to measure the amount of melanin content followed a modified method of Bilodeau et al. ${ }^{21)}$ Briefly, B16 cells $\left(5 \times 10^{4}\right)$ were plated on 24 -well, multi-dishes and incubated in the presence or absence of $100 \mathrm{~nm} \alpha$-MSH. Cells were then incubated for $24 \mathrm{~h}$ with or without hyperin and quercetin at concentrations ranging from 5 to $50 \mu \mathrm{M}$. After washing twice with PBS, samples were dissolved in $100 \mu \mathrm{L}$ of $1 \mathrm{~N} \mathrm{NaOH}$. The samples were incubated at $60^{\circ} \mathrm{C}$ for $1 \mathrm{~h}$ and mixed to solubilize the melanin. Absorbance was measured at $405 \mathrm{~nm}$ and compared with a standard curve of synthetic melanin.

Protein Assay The concentration of protein was examined by a bicinchoninic acid protein assay. ${ }^{22)}$ All samples were assayed in triplicate.

Statistical Analysis Data were analyzed as mean \pm standard error $(n=5)$ and the biological significance $p<0.05$ was

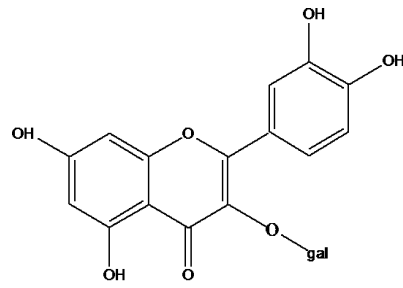

Hyperin

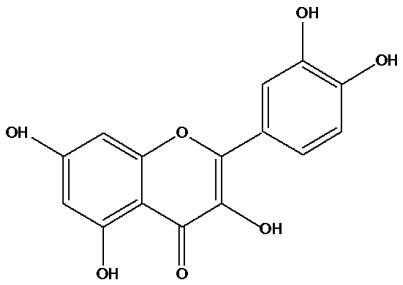

Quercetin
Fig. 1. Chemical Structures of Hyperin and Quercetin

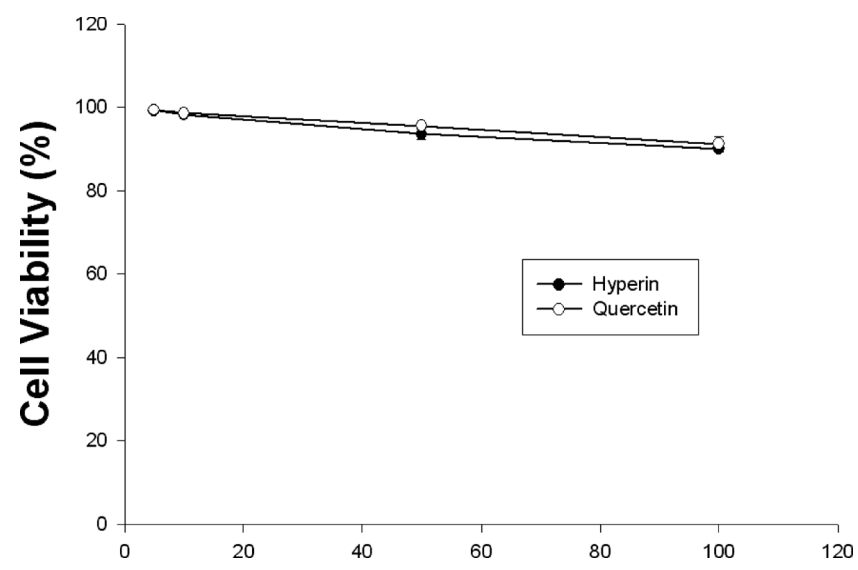

Fig. 2. The Effect of Hyperin and Quercetin on Cell Viability

Cells treated with various doses of the hyperin and quercetin were evaluated by the MTT assay. Data are expressed as \% of cell viability.

determined by the Student's $t$-test.

\section{RESULTS AND DISCUSSION}

This study was designed to determine the effects of hyperin and quercetin on oxidative stress-induced melanogenesis. To the best of my knowledge, this present study shows the first evidence that both hyperin and quercetin have a strong suppressive effect on oxidative stress-related melanogenesis in B16 cells.

It has been reported that hyperin and quercetin possess antioxidant properties. ${ }^{23}$ ) Their structural analysis (see the structures of hyperin and quercetin in Fig. 1) reveals that the unique difference between quercetin and hyperin lies in position 3 of ring $\mathrm{C}$, where a hydroxyl group and galactose exist, respectively. ${ }^{24}$ The hydroxyl group on position 3 in ring $\mathrm{C}$ is associated with hydroxyl radical-scavenging activity. Therefore, the assumption is that quercetin would show more potent hydroxyl radical scavenging activity than hyperin ${ }^{24)}$ and would therefore bear out our results that quercetin showed stronger antioxidant activity than hyperin due to their structural differences. Findings in the current study also correlate with previous reports indicating that aglycone exhibits a more potent apoptotic property than the corresponding glycosylated compound, ${ }^{25}$ and TPA-induced prostaglandin $\mathrm{E}_{2}\left(\mathrm{PGE}_{2}\right)$ production in rat peritoneal macrophages. ${ }^{26)}$

The potential use of hyperin and quercetin as skin-lightening agents also was evaluated by measuring cell cytotoxicity. As displayed in Fig. 2, hyperin and quercetin were found to 
Table 1. Effects of Hyperin and Quercetin on $\mathrm{ONOO}^{-}$Scavenging Activity in Vitro

\begin{tabular}{cc}
\hline \hline Compound & $\mathrm{IC}_{50}(\mu \mathrm{M})$ \\
\hline Hyperin & $0.89 \pm 0.14$ \\
Quercetin & $0.78 \pm 0.05$ \\
Penicillamine & $3.01 \pm 0.47$ \\
\hline
\end{tabular}

Table 2. Effects of Hyperin and Quercetin on Melanogenesis

\begin{tabular}{lc}
\hline \hline \multicolumn{1}{c}{ Group } & Melanin content $(\%)$ \\
\hline Control & $11.63 \pm 0.32$ \\
Hyperin $(5 \mu \mathrm{M})$ & $8.23 \pm 1.20^{* *}$ \\
Hyperin $(10 \mu \mathrm{M})$ & $6.22 \pm 0.92^{* *}$ \\
Hyperin $(50 \mu \mathrm{M})$ & $4.12 \pm 0.23^{* * *}$ \\
Quercetin $(5 \mu \mathrm{M})$ & $3.12 \pm 0.03^{*}$ \\
Quercetin $(10 \mu \mathrm{M})$ & $2.01 \pm 0.91^{*}$ \\
Quercetin $(50 \mu \mathrm{M})$ & $1.12 \pm 0.33^{* *}$ \\
\hline
\end{tabular}

Each value represents the mean \pm S.E.M. of three determinations. Statistically significant differences in comparison with control group $\left({ }^{*} p<0.05,{ }^{*} p<0.01\right.$, $* * * p<0.001)$.

Table 3. Effects of Hyperin and Quercetin on Total RS Production

\begin{tabular}{lc}
\hline \hline \multicolumn{1}{c}{ Group } & $\begin{array}{c}\text { Total RS production (fluorescence/ } \\
\text { min/mg protein) }\end{array}$ \\
\hline Control & $9.62 \pm 0.46$ \\
Hyperin $(5 \mu \mathrm{M})$ & $8.01 \pm 1.21^{* *}$ \\
Hyperin $(10 \mu \mathrm{M})$ & $7.34 \pm 1.01^{* *}$ \\
Hyperin $(50 \mu \mathrm{M})$ & $5.83 \pm 0.32^{* * *}$ \\
Quercetin $(5 \mu \mathrm{M})$ & $2.21 \pm 0.67^{*}$ \\
Quercetin $(10 \mu \mathrm{M})$ & $1.53 \pm 0.87^{*}$ \\
Quercetin $(50 \mu \mathrm{M})$ & $0.78 \pm 0.29^{* *}$ \\
\hline
\end{tabular}

Each value represents the mean \pm S.E.M. of three determinations. Statistically significant differences in comparison with control group $(* p<0.05, * * p<0.01$, $* * * p<0.001)$.

have no significant cytotoxic effects at any of the concentrations tested. Because oxidative stressors and RS are closely associated with melanogenesis, ${ }^{3-5)}$ and melanin synthesis is enhanced under increased oxidative stress that generally leads to hyperpigmentation, the anti-oxidative action of hyperin and quercetin was then measured (Table 1).

We next sought to experimentally substantiate the suppression of melanogenesis in B16 cells by hyperin and quercetin; the results are shown in Table 2. Additionally, our results showing the efficacy of hyperin and quercetin on various other oxidative species are displayed in Table 3. Both hyperin and quercetin effectively inhibited total RS generation, implying the possibility that a number of hydroxyl groups of hyperin and quercetin that are likely responsible for the suppression of total RS, which is consistent with previous studies. ${ }^{5,11,23)}$

Data shown in Figs. 3-5 further support the notion that that ${ }^{\circ} \mathrm{O}_{2}, \mathrm{NO}^{\circ}$, and $\mathrm{ONOO}^{-}$production were blunted by hyperin and quercetin. Interestingly, both hyperin and quercetin showed strong $\mathrm{ONOO}^{-}$scavenging activity both in vitro and in B16 cells, indicating that controlling $\mathrm{ONOO}^{-}$is one of the major contributing factors in melanogenesis inhibition by hyperin and quercetin. This fact is supported by the previous study ${ }^{27)}$ showing that the $\mathrm{ONOO}^{-}$scavenging property is a crucial factor in melanogenic regulation. In addition,

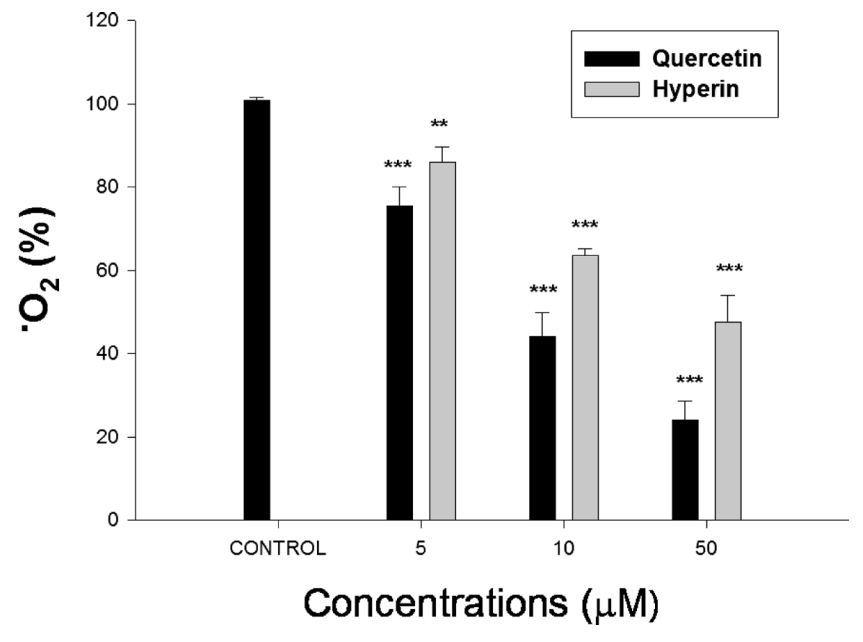

Fig. 3. Effect of the Hyperin and Quercetin on ${ }^{\circ} \mathrm{O}_{2}$ Levels

Each value represents the mean \pm S.E.M. of at least three determinations that are significantly different from control group $(* * p<0.01, * * * p<0.001)$.

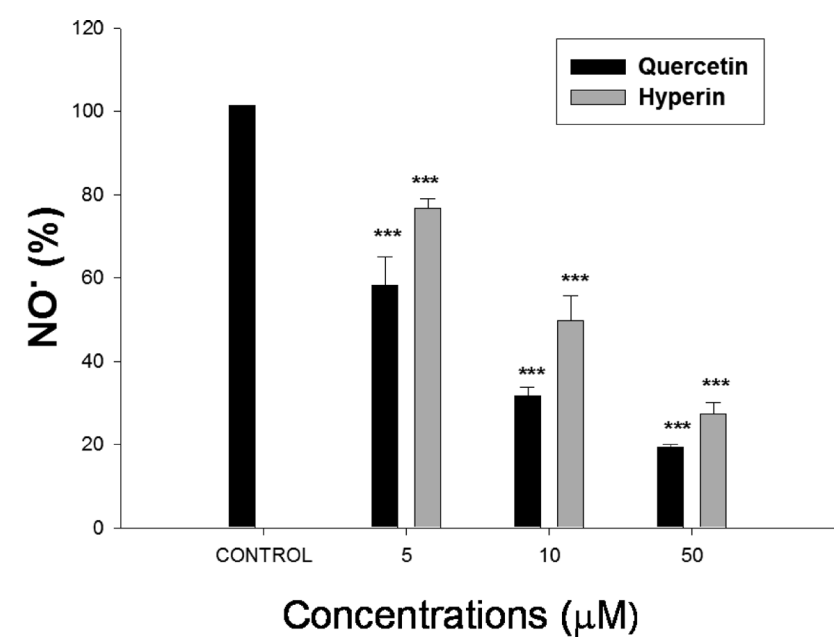

Fig. 4. Suppressive Action of Hyperin and Quercetin on NO Levels Results are expressed as the mean \pm S.E.M. of at least three determinations. Statistically significant differences from the control group are noted as $* * * p<0.001$.

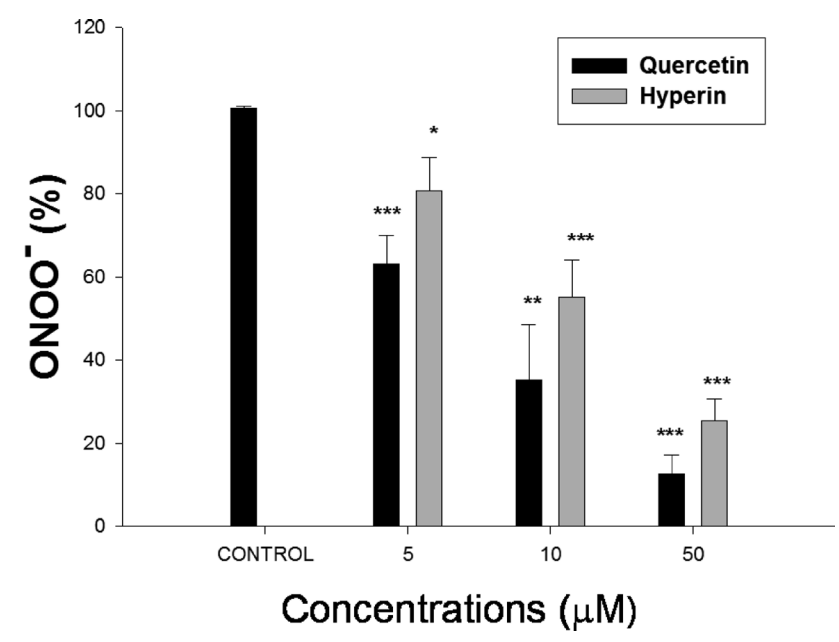

Fig. 5. The Inhibitory Property of Hyperin and Quercetin on ONOO-

Results are expressed as the mean \pm S.E.M. of at least three determinations. Statistically significant differences from the control group are noted as $* p<0.05$, $* * p<0.01, * * * p<0.001$. 


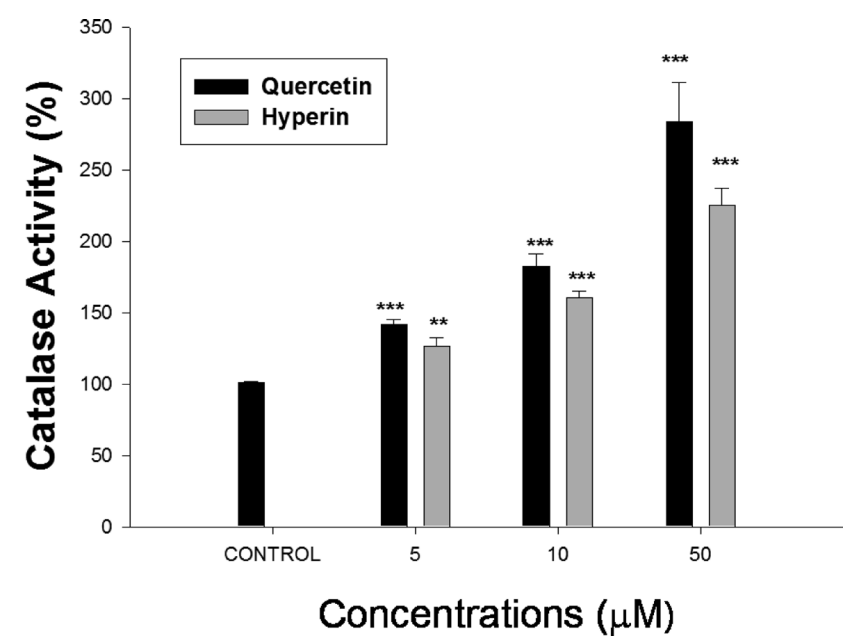

Fig. 6. The Augmenting Effect of Hyperin and Quercetin on Catalase Activity

Each value represents the mean \pm S.E.M. of at least three determinations that are significantly different from the control group $(* * p<0.01, * * * p<0.001)$

we recently reported that reducing total $\mathrm{RS}, \mathrm{O}_{2}, \mathrm{NO}^{\circ}$, and $\mathrm{ONOO}^{-}$may well be major underlying factors in the suppression of melanogenesis. ${ }^{8)}$

One of the novel findings of the current study is the control of catalase activity by hyperin and quercetin. Figure 6 reveals that hyperin and quercetin modulated catalase activity, indicating that in B16 cells, the modulation of catalase by hyperin and quercetin correlates with regulation of melanogensis. ${ }^{28)}$

It was recently reported that the disturbance of RS regulation results in redox imbalance, causing oxidative insult. ${ }^{29,30)}$ Figures $7 \mathrm{~A}-\mathrm{C}$ show that hyperin and quercetin enhanced $\mathrm{GSH}$ levels and the GSH/GSSG ratio while suppressing GSSG levels, indicating the ability of hyperin and quercetin to accentuate the cellular redox status in B16 cells. These data imply that sustaining redox balance by hyperin and quercetin also might be an important contributing factor for melanogenesis suppression, which is consistent with recent reports. ${ }^{31,32)}$

Thus, the major findings of our present work are that hyperin and quercetin exert a broad and potent anti-oxidative efficacy against total $\mathrm{RS},{ }^{\circ} \mathrm{O}_{2}, \mathrm{NO}^{\circ}$, and $\mathrm{ONOO}^{-}$and enhance the GSH/GSSG ratio and catalase activity in B16 cells. The present study demonstrated that hyperin and quercetin modulate oxidative stress-induced melanogenesis not only by suppressing total $\mathrm{RS},{ }^{\circ} \mathrm{O}_{2}, \mathrm{NO}^{\circ}, \mathrm{ONOO}^{-}$, but also by boosting the anti-oxidative $\mathrm{ONOO}^{-}$scavenging capacity, the $\mathrm{GSH} /$ GSSG ratio and catalase activity in B16 cells. In conclusion, this present work strongly indicates that hyperin and quercetin can be possible potent oxidative stress-induced melanogenic inhibitors. Based on these findings, we postulate that the amelioration of oxidative stress might be the plausible mechanism underlying the inhibition of melanogenesis by hyperin and quercetin, which, in turn, may contribute to the development of new depigmenting agents. However, more molecular and clinical investigations are warranted to elucidate the precise biological mechanisms of hyperin and quercetin.

Acknowledgments This work was supported by the Busan Women's College Research Grant of 2012 Coll-40. I also thank the Aging Tissue Bank for distributing research resources.
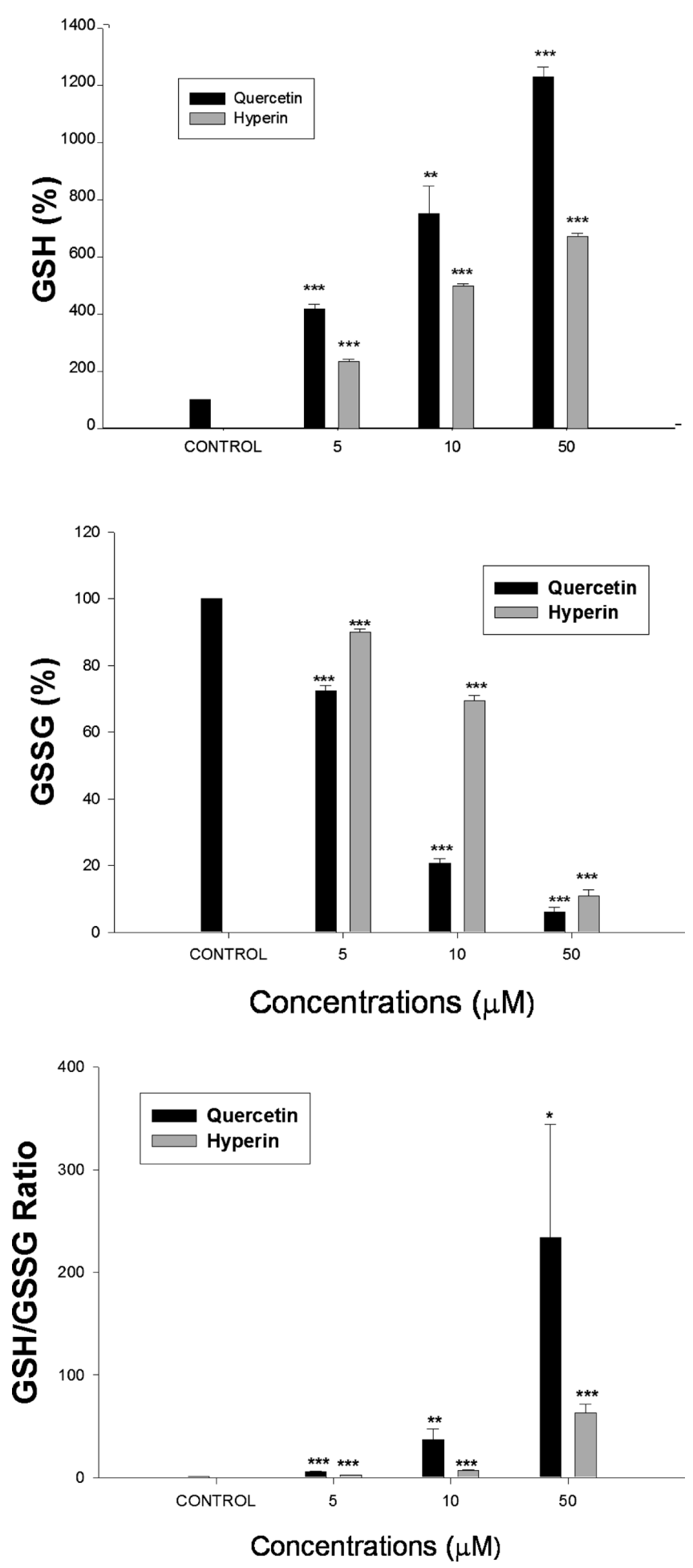

Fig. 7. The Effect of Hyperin and Quercetin on (A) GSH Level (B) GSSG Level and (C) GSH/GSSG Ratio

Each value represents the mean \pm S.E.M. of at least three determinations that are significantly different from the control group $(* p<0.05$, ** $p<0.01$, *** $p<0.001$ ).

\section{REFERENCES}

1) Gillbro JM, Olsson MJ. The melanogenesis and mechanisms of skin-lightening agents-existing and new approaches. Int. J. Cosmet. Sci., 33, 210-221 (2011).

2) Eves PC, MacNeil S, Haycock JW. $\alpha$-Melanocyte stimulating hormone, inflammation and human melanoma. Peptides, 27, 444-452 
(2006).

3) Kohen R. Skin antioxidants: their role in aging and in oxidative stress-New approaches for their evaluation. Biomed. Pharmacother., 53, 181-192 (1999).

4) Afaq F, Mukhtar H. Botanical antioxidants in the prevention of photocarcinogenesis and photoaging. Exp. Dermatol., 15, 678-684 (2006).

5) Yokozawa T, Kim YJ. Piceatannol inhibits melanogenesis by its antioxidative actions. Biol. Pharm. Bull., 30, 2007-2011 (2007).

6) Yamaguchi Y, Brenner M, Hearing VJ. The regulation of skin pigmentation. J. Biol. Chem., 282, 27557-27561 (2007).

7) Kim YJ, No JK, Lee JS, Kim MS, Chung HY. Antimelanogenic activity of 3,4-dihydroxyacetophenone: inhibition of tyrosinase and MITF. Biosci. Biotechnol. Biochem., 70, 532-534 (2006).

8) Kim YJ, Kang KS, Yokozawa T. The anti-melanogenic effect of pycnogenol by its anti-oxidative actions. Food Chem. Toxicol., 46, 2466-2471 (2008).

9) Kim YJ, No JK, Lee JH, Chung HY. 4,4'-Dihydroxybiphenyl as a new potent tyrosinase inhibitor. Biol. Pharm. Bull., 28, 323-327 (2005).

10) No JK, Kim YJ, Lee JS, Chung HY. Inhibition of melanogenic activity by $4,4^{\prime}$-dihydroxybiphenyl in melanoma cells. Biol. Pharm. Bull., 29, 14-16 (2006).

11) Kim YJ. Antimelanogenic and antioxidant properties of gallic acid. Biol. Pharm. Bull., 30, 1052-1055 (2007).

12) Bitis L, Kultur S, Melikoglu G, Ozsoy N, Can A. Flavonoids and antioxidant activity of Rosa agrestis leaves. Nat. Prod. Res., 24, 580-589 (2010).

13) Li J, Huang H, Zhou W, Feng M, Zhou P. Anti-hepatitis B virus activities of Geranium carolinianum L. extracts and identification of the active components. Biol. Pharm. Bull., 31, 743-747 (2008).

14) Tada H, Shiho O, Kuroshima K, Koyama M, Tsukamoto K. An improved colorimetric assay for interleukin 2. J. Immunol. Methods, 93, 157-165 (1986)

15) Kooy NW, Royall JA, Ischiropoulos H, Beckman JS. Peroxynitritemediated oxidation of dihydrorhodamine 123. Free Radic. Biol. Med., 16, 149-156 (1994).

16) Paraidathathu $T$, de Groot H, Kehrer JP. Production of reactive oxygen by mitochondria from normoxic and hypoxic rat heart tissue. Free Radic. Biol. Med., 13, 289-297 (1992).

17) Green LC, Wagner DA, Glogowski J, Skipper PL, Wishnok JS, Tannenbaum SR. Analysis of nitrate, nitrite, and $\left[{ }^{15} \mathrm{~N}\right]$ nitrate in biological fluids. Anal. Biochem., 126, 131-138 (1982).

18) Ewing JF, Janero DR. Microplate superoxide dismutase assay employing a nonenzymatic superoxide generator. Anal. Biochem., 232, 243-248 (1995).

19) Aebi H. Catalase in vitro. Methods Enzymol., 105, 121-126 (1984).

20) Pandey A, Katiyar SS. Inactivation of yeast glutathione reductase by $O$-phthalaldehyde. J. Enzyme Inhib., 11, 141-149 (1996).
21) Bilodeau ML, Greulich JD, Hullinger RL, Bertolotto C, Ballotti R, Andrisani OM. BMP-2 stimulates tyrosinase gene expression and melanogenesis in differentiated melanocytes. Pigment Cell Res., 14, 328-336 (2001).

22) Hall AM, Croy V, Chan T, Ruff D, Kuczek T, Chang C. Bicinchoninic acid protein assay in the determination of adriamycin cytotoxicity modulated by the MDR glycoprotein. J. Nat. Prod., 59, 35-40 (1996).

23) Nerya $\mathrm{O}$, Musa R, Khatib S, Tamir S, Vaya J. Chalcones as potent tyrosinase inhibitors: the effect of hydroxyl positions and numbers. Phytochemistry, 65, 1389-1395 (2004).

24) Chen JW, Zhu ZQ, Hu TX, Zhu DY. Structure-activity relationship of natural flavonoids in hydroxyl radical-scavenging effects. Acta Pharmacol. Sin., 23, 667-672 (2002).

25) Hong J, Yokomakura A, Nakano Y, Ishihara K, Kaneda M, Onodera M, Nakahama K, Morita I, Niikura K, Ahn JW, Zee O, Ohuchi K. Inhibition of vacuolar-type (H+)-ATPase by the cytostatic macrolide apicularen A and its role in apicularen A-induced apoptosis in RAW 264.7 cells. FEBS Lett., 580, 2723-2730 (2006).

26) Yamaki K, Kim DH, Ryu N, Kim YP, Shin KH, Ohuchi K. Effects of naturally occurring isoflavones on prostaglandin E2 production. Planta Med., 68, 97-100 (2002).

27) Akihisa $T$, Noto $T$, Takahashi A, Fujita Y, Banno N, Tokuda H, Koike K, Suzuki T, Yasukawa K, Kimura Y. Melanogenesis inhibitory, anti-inflammatory, and chemopreventive effects of limonoids from the seeds of Azadirachta indicia A. Juss. (neem). J. Oleo Sci., 58, 581-594 (2009).

28) Panich U, Kongtaphan K, Onkoksoong T, Jaemsak K, Phadungrakwittaya R, Thaworn A, Akarasereenont P, Wongkajornsilp A. Modulation of antioxidant defense by Alpinia galanga and Curcuma aromatica extracts correlates with their inhibition of UVA-induced melanogenesis. Cell Biol. Toxicol., 26, 103-116 (2010).

29) Kim YJ, Kim YA, Yokozawa T. Attenuation of oxidative stress and inflammation by gravinol in high glucose-exposed renal tubular epithelial cells. Toxicology, 270, 106-111 (2010).

30) Kim YJ, Yokozawa T. Modulation of oxidative stress and melanogenesis by proanthocyanidins. Biol. Pharm. Bull., 32, 1155-1159 (2009).

31) Panich U, Onkoksoong T, Limsaengurai $S$, Akarasereenont $P$, Wongkajornsilp AJ. UVA-induced melanogenesis and modulation of glutathione redox system in different melanoma cell lines: the protective effect of gallic acid. J. Photochem. Photobiol. B, 108, 16-22 (2012).

32) Panich U, Tangsupa-a-nan V, Onkoksoong T, Kongtaphan K, Kasetsinsombat K, Akarasereenont P, Wongkajornsilp A. Inhibition of UVA-mediated melanogenesis by ascorbic acid through modulation of antioxidant defense and nitric oxide system. Arch. Pharm. Res., 34, 811-820 (2011). 